\title{
Interaction of Prostaglandins and Histamine with Enzymes of Cyclic AMP Metabolism from Guinea Pig Gastric Mucosa
}

\author{
Armin Wollin, Charles F. Code, and Thomas P. Dousa \\ From the Departments of Physiology and Medicine, Mayo Clinic and \\ Foundation, Rochester, Minnesota 55901
}

A в S T R A c T Prostaglandins (PGE $\left., \mathrm{PGE}_{2}, \mathrm{PGA}_{1}\right)$ and histamine have opposing effects on gastric $\mathrm{HCl}$ secretion, but we found that both stimulate adenylate cyclase activity in cell-free membrane preparations of guinea pig gastric fundic mucosa. The stimulatory effect of prostaglandins was found in this study to be specific and dose-dependent over a concentration range from $10^{-7}$ to $10^{-4} \mathrm{M}$. In similar preparations from antral regions of guinea pig gastric mucosa, the adenylate cyclase was stimulated only by $\mathrm{PGE}_{1}, \mathrm{PGE}_{2}$, and $\mathrm{PGA}_{1}$ and not by histamine. Maximum stimulating doses of $\mathrm{PGE}_{1}, \mathrm{PGE}_{2}$, or PGA1, and of histamine had an additive effect on the adenylate cyclase activity from fundic gastric mucosa. Metiamide, a histamine $\mathrm{H}_{2}$-receptor antagonist, inhibited the stimulation of fundic mucosa adenylate cyclase by histamine but did not interfere with the stimulation by prostaglandins. Cyclic AMP phosphodiesterase activity of guinea pig gastric mucosa was unaffected by $\mathrm{PGE}_{1}$ and $\mathrm{PGE}_{2}$ or by histamine, and was slightly depressed by $P G A_{1}$. These results indicate that histamine and prostaglandins stimulate two different adenylate cyclase systems both present in guinea pig gastric mucosa tissue. Therefore, the known inhibitory effect of prostaglandins on gastric acid secretion is not related to the interference with the stimulation of the histamine $\mathrm{H}_{2}$-receptor-sensitive adenylate cyclase complex by histamine nor do prostaglandins accelerate cyclic AMP

This work was presented in part at the Meeting of the Midwest Section of the American Federation for Clinical Research, Chicago, Ill., October 1974 (Clin. Res. 22: 606A), and at the 32nd Annual Meeting of the American Federation for Clinical Research, Atlantic City, N. J., May 1975 (Clin. Res. 23: 206A).

Dr. Wollin is a Fellow of the Canadian Medical Research Council and Dr. Dousa is an Established Investigator for the American Heart Association.

Received for publication 31 July 1975 and in revised form 30 January 1976. breakdown by cyclic AMP phosphodiesterase to reduce cyclic AMP levels.

\section{INTRODUCTION}

Histamine is a potent stimulator of $\mathrm{HCl}$ secretion, while prostaglandins are inhibitory (1-3). The cellular mechanisms through which these humoral agents exert their regulatory effects on $\mathrm{HCl}$ secretion have not yet been elucidated. A number of studies in mammalian as well as in nonmammalian species indicate that histamine's action on oxyntic cells is mediated at least in some species through stimulation of cyclic AMP formation. The evidence for such mechanism is based mainly on observations that histamine stimulates adenylate cyclase in cellfree preparations (4-12) and also causes the accumulation of cyclic AMP in unbroken ceil preparations (tissue slices) of fundic gastric mucosa (13-15), concomitant with in situ activation of cyclic AMP-dependent protein kinase (15). Stimulation of gastric mucosa cyclic AMP production by histamine is probably due to its interaction with the $\mathrm{H}_{2}$ receptors since specific histamine $\mathrm{H}_{2}$-receptor antagonists inhibit the effect of histamine on both cyciic AMP formation and $\mathrm{HCl}$ secretion $(11,12,16-18)$.

In contrast to this, the cellular mechanism by which prostaglandins inhibit gastric secretion is obscure. Some indirect observations suggest that prostaglandins block $\mathrm{HCl}$ secretion by inhibiting cyclic AMP formation in gastric mucosa stimulated by secretagogues such as histamine $(1,13,19-21)$. On the other hand, in a preliminary study, $\mathrm{PGE}_{1}{ }^{1}$ was reported to stimulate the adenylate cyclase of guinea pig gastric mucosa (4), a finding which does not support the earlier proposition.

To clarify the apparent discrepancies in the proposed cellular mechanism of the inhibition by prostaglandins (19), we have examined the effects of both prosta-

\footnotetext{
${ }^{1}$ Abbreviations used in this paper: $\mathrm{PGE}_{1}$, prostaglandin $\mathrm{E}_{1} ; \mathrm{PGE}_{2}$, prostaglandin $\mathrm{E}_{2} ; \mathrm{PGA}_{1}$, prostaglandin $\mathrm{A}_{1}$.
} 
glandins and histamine on the enzymes of cyclic AMP metabolism of the acid-secreting (fundic) and nonacidsecreting (antral) gastric mucosa of the guinea pig. The results show that prostaglandins and histamine both stimulate cyclic AMP formation in guinea pig gastric mucosa, but their effects differ in the fundic and antral regions, indicating that they act on two different adenylate cyclase systems.

\section{METHODS}

Guinea pigs maintained on ad lib. diet were killed by a blow on the head and exsanguination. The stomach was quickly removed, opened by a cut along the greater curvature, and repeatedly rinsed with ice-cold isotonic saline to remove adherent contents. The stomach was then stretched on an ice-cold plate, and the mucosa scraped from muscle layer. All further preparatory steps were done at $0-2^{\circ} \mathrm{C}$. The mucosa from fundic and antral regions were removed separately, leaving untouched the transitional zone of about $1 \mathrm{~cm}$ between the two regions. The identity of the mucosa from both regions was verified histologically, using conventional hematoxylin-eosin stain. The mucosa was homogenized in a glass-Teflon homogenizer (two strokes) in a medium containing $0.25 \mathrm{M}$ sucrose, $5 \mathrm{mM}$ Tris, $3 \mathrm{mM} \mathrm{MgCl}_{2}$, and 1 mM EDTA, pH 7.4 (1:4 wt/vol). After centrifugation of the homogenate at $1,000 \mathrm{~g}$ for $15 \mathrm{~min}$, the supernate was quickly frozen and stored at $-80^{\circ} \mathrm{C}$, and the sediment was resuspended in approximately $30 \mathrm{ml}$ of ice-cold medium of the above described composition without sucrose. The suspension was centrifuged again at $1,000 \mathrm{~g}$ for $15 \mathrm{~min}$. The pellet was then resuspended in the medium without sucrose using a ratio of $1 \mathrm{~g}$ of mucosa tissue for $1 \mathrm{ml}$ of buffer, divided into several portions, and quickly frozen in dry ice and stored at $-80^{\circ} \mathrm{C}$. This preparation served as a source of adenylate cyclase.

The adenylate cyclase was assayed using the method described in a previous study (22). The enzyme tabout $50 \mu \mathrm{g}$ protein per tube) was incubated for $20 \mathrm{~min}$ at $37^{\circ} \mathrm{C}$ in a medium (total vol $50 \mu \mathrm{l}$ ) of the following composition: $0.1 \mathrm{mM}$ ATP (10 $\mathrm{cpm} /$ tube $), 4 \mathrm{mM} \mathrm{MgCl}_{2}, 0.1 \mathrm{mM}$ EDTA, $1 \mathrm{mg} / \mathrm{ml}$ of bovine serum albumin, $0.5 \mathrm{mM}$ cyclic AMP, $25 \mathrm{mM}$ creatine phosphate, $0.1 \mathrm{mg} / \mathrm{ml}$ creatine kinase
(Calbiochem, San Diego, Calif.), and $40 \mathrm{mM}$ Tris- $\mathrm{HCl}$ buffer $(\mathrm{pH} 7.4)$. The incubation reaction was stopped by the addition of a 5- $\mu$ l mixture containing $25 \mathrm{mM}$ ATP, $25 \mathrm{mM}$ $5^{\prime}$-AMP, $25 \mathrm{mM}$ cyclic AMP, and $250 \mathrm{mM}$ EDTA and by subsequent heating in a boiling water bath for $3 \mathrm{~min}$. The separation of $\left[{ }^{32} \mathrm{P}\right]$ cyclic AMP from ATP and other radioactive materials was done by thin-layer chromatography, using cellulose polyethyleninmine-impregnated thin-layer plates and $0.25 \mathrm{M}$ lithium chloride as a developing agent (23).

Cyclic AMP phosphodiesterase activity, which was shown to be located mostly in cytosol (24), was assayed in the supernatant preparation from the first centrifugation, employing the principle developed by Thompson and Appleman (25) and employed in a previous study (11). The protein content in enzyme extracts was determined by method of Lowry et al. (26), and the enzyme activities were expressed in terms of picomoles per minute per milligrams of the enzyme protein.

The stock solutions of the prostaglandins and arachidonic acid were prepared in ethanol and kept at $-10^{\circ} \mathrm{C}$. Before the experiment, the appropriate dilutions were made with $5 \mathrm{mM}$ Tris- $\mathrm{HCl}$ buffer ( $\mathrm{pH} \mathrm{7.4).} \mathrm{It} \mathrm{was} \mathrm{observed} \mathrm{in} \mathrm{the}$ preliminary experiments that ethanol in high concentrations can reduce both the adenylate cyclase and cyclic AMP phosphodiesterase activities. For example, $10 \%$ ethanol content in the reaction mixture reduced the basal activity of adenylate cyclase by about $50-60 \%$, but with a final concentration of $1 \%$, no inhibition was observed. Therefore, in the adenylate cyclase assays, the ethanol content was kept at $1 \%$ or less. In the cyclic AMP phosphodiesterase assays, larger quantities of prostaglandins were required for the assay and, therefore, the ethanol concentration was higher. In that case, the enzyme activity was compared to control incubations containing the same ethanol concentration as in the incubations containing the tested agents. However, the prostaglandins' relatively low solubility in aqueous medium prevented the testing at higher concentrations.

Histamine was purchased from Calbiochem; metiamide was a gift from Smith, Kline \& French Laboratories, Ltd. (Welwyn Garden City, England). The $\mathrm{PGE}_{1}, \mathrm{PGE}_{2}$, and $\mathrm{PGA}_{1}$ were kindly supplied by the Upjohn Co. (Kalamazoo, Mich.). $\alpha-\left[{ }^{22} \mathrm{P}\right]$ ATP for the adenylate cyclase assay was a product from International Chemical and Nuclear Corp.

TABLE I

Effects of Histamine, Prostaglandins, and Arachidonic Acid on Fundic and Antral Mucosa Adenylate Cyclase

\begin{tabular}{|c|c|c|c|c|}
\hline & \multicolumn{4}{|c|}{ Adenylate cyclase activity } \\
\hline & Fundic mucosa & $P$ valueł & Antral mucosa & $P$ value \\
\hline & \multicolumn{4}{|c|}{ pmol cyclic $A M P / \min / m g$ protein* } \\
\hline Basal activity & $9.2 \pm 0.4(40) \S$ & - & $12.3 \pm 0.8(18)$ & - \\
\hline+ Histamine $\left(10^{-4} \mathrm{M}\right)$ & $32.0 \pm 2.6(27)$ & $<0.001$ & $13.5 \pm 1.2(9)$ & NS \\
\hline$+\operatorname{PGE}_{1}\left(10^{-4} \mathrm{M}\right)$ & $27.4 \pm 2.0(16)$ & $<0.001$ & $35.4 \pm 6.7(6)$ & $<0.01$ \\
\hline$+\mathrm{PGE}_{2}\left(10^{-4} \mathrm{M}\right)$ & $21.8 \pm 1.3(16)$ & $<0.001$ & $36.6 \pm 4.4(4)$ & $<0.01$ \\
\hline$+\mathrm{PGA}_{1}\left(10^{-4} \mathrm{M}\right)$ & $20.1 \pm 1.3(15)$ & $<0.001$ & $42.0 \pm 5.6(6)$ & $<0.01$ \\
\hline + Arachidonic acid $\left(10^{-4} \mathrm{M}\right)$ & $11.6 \pm 1.6(7)$ & NS & $14.7 \pm 2.2(6)$ & NS \\
\hline
\end{tabular}

* Mean \pm SE.

‡ For significance of differences between basal activity and activity after addition of tested agent; NS denotes $P>0.05$ ( $t$ test).

$\$$ Number of observations.in parentheses. 
TABLE II

Additive Stimulation of Adenylate Cyclase from Fundic Mucosa by Maximum Stimulatory Doses of Histamine $\left(10^{-4} \mathrm{M}\right)$ and Prostaglandins $\left(10^{-4} \mathrm{M}\right)$

\begin{tabular}{|c|c|c|c|}
\hline & \multicolumn{3}{|c|}{ Adenylate cyclase activity } \\
\hline & $\begin{array}{c}\text { Calculated additive } \\
\text { effect } \ddagger\end{array}$ & $\begin{array}{c}\text { Tested additive } \\
\text { effect } \S\end{array}$ & $\begin{array}{l}\text { Significance } \\
\text { of differencell }\end{array}$ \\
\hline & \multicolumn{2}{|c|}{ pmol cyclic $A M P / \min / m g$ protein* } & \\
\hline $\begin{aligned} \text { Histamine } & +\mathrm{PGE}_{1} \\
& +\mathrm{PGE}_{2} \\
& +\mathrm{PGA}_{1}\end{aligned}$ & $\begin{array}{l}39.5 \pm 3.2(12) \Psi \\
38.6 \pm 3.1(14) \\
40.0 \pm 3.4(14)\end{array}$ & $\begin{array}{l}42.8 \pm 3.5(12) \\
35.7 \pm 4.7(14) \\
40.1 \pm 2.8(14)\end{array}$ & $\begin{array}{l}\text { NS } \\
\text { NS } \\
\text { NS }\end{array}$ \\
\hline
\end{tabular}

* Mean \pm SE.

$\ddagger$ Values represent arithmetic sums of increases in the adenylate cyclase activity over basal activity by two agents tested separately.

$\$$ Values represent the increase in the adenylate cyclase activity over basal activity by two agents added together into incubation mixture.

$\|$ Significance evaluated by $t$ test NS $=P>0.05$.

I Number of observations in parentheses.

(Irvine, Calif.) and cyclic [ $\left.{ }^{3} \mathrm{H}\right]$ AMP by New England Nuclear (Boston, Mass.). All other chemicals or biochemicals were of the highest purity grade and purchased from the standard suppliers.

\section{RESULTS}

The adenylate cyclase prepared from the two different functional regions of the guinea pig gastric mucosa differed in responsiveness to histamine and prostaglandins. While histamine increased the adenylate cyclase activity from the fundic mucosa more than three times over basal, it did not increase significantly the adenylate cyclase activity from the antral mucosa (Table I). In contrast to this, $\mathrm{PGE}_{1}, \mathrm{PGE}_{2}$, and $\mathrm{PGA}_{\mathbf{1}}$ in concentration of $10^{-4} \mathrm{M}$ stimulated not only fundic but also antral mucosal adenylate cyclase preparations. The response to the prostaglandins in the antral mucosa preparation appeared to be greater than in the preparations from the fundic region (Table I). Arachidonic acid, a precursor of prostaglandins, had no effect on the adenylate cyclase activity, suggesting that the stimulation of adenylate cyclase by prostaglandins is specific and is unlikely due to general physicochemical properties of the longchained fatty acid.

Both histamine and prostaglandins stimulated the adenylate cyclase preparations from acid-secreting (fundic) mucosa; yet both agents have been reported as having opposite effects on $\mathrm{HCl}$ secretion in vivo (1-3, 13, 19). To resolve the question whether histamine and prostaglandins act on the same adenylate cyclase system, both agents were tested either separately or added together to the same reaction mixtures containing fundic mucosa adenylate cyclase.

Before exploring possible interactions between the two types of stimulants, the dose dependence of their action was tested. We found that stimulation by prostaglandins $\mathrm{PGE}_{1}, \mathrm{PGE}_{2}$, and $\mathrm{PGA}_{1}$ or by histamine was dose-

TABLE III

Effect of Metiamide, a Histamine $\mathrm{H}_{2}$-Receptor Antagonist, on the Stimulation of Fundic Gastric Mucosa Adenylate Cyclase by Histamine and Prostaglandins

\begin{tabular}{lccc}
\hline & \multicolumn{3}{c}{ Adenylate cyclase activity } \\
\cline { 2 - 4 } & Without antagonist & $\begin{array}{c}\text { Metiamide (10-4 M) } \\
\text { added }\end{array}$ & $P$ valuef \\
\hline & \multicolumn{3}{c}{ pmol cyclic $A M P /$ min $/$ mg protein* } \\
Basal activity & $9.4 \pm 0.6(13) \&$ & $7.7 \pm 0.8(13)$ & NS \\
Histamine $\left(10^{-4} \mathrm{M}\right)$ & $33.5 \pm 2.6(13)$ & $14.6 \pm 0.8(13)$ & $<0.001$ \\
PGE $_{1}\left(10^{-5} \mathrm{M}\right)$ & $22.8 \pm 1.8(8)$ & $21.1 \pm 1.7(8)$ & $\mathrm{NS}$ \\
PGE $_{2}\left(10^{-6} \mathrm{M}\right)$ & $19.6 \pm 3.0(8)$ & $16.4 \pm 1.1(8)$ & $\mathrm{NS}$ \\
PGA $_{1}\left(10^{-5} \mathrm{M}\right)$ & $14.9 \pm 1.2(7)$ & $12.1 \pm 1.7(7)$ & $\mathrm{NS}$ \\
\hline
\end{tabular}

* Mean \pm SE.

¥ For significance of differences between activities without and with addition of metiamide; NS denotes $P>0.05$ ( $t$ test).

$\$$ Number of observations in parentheses. 

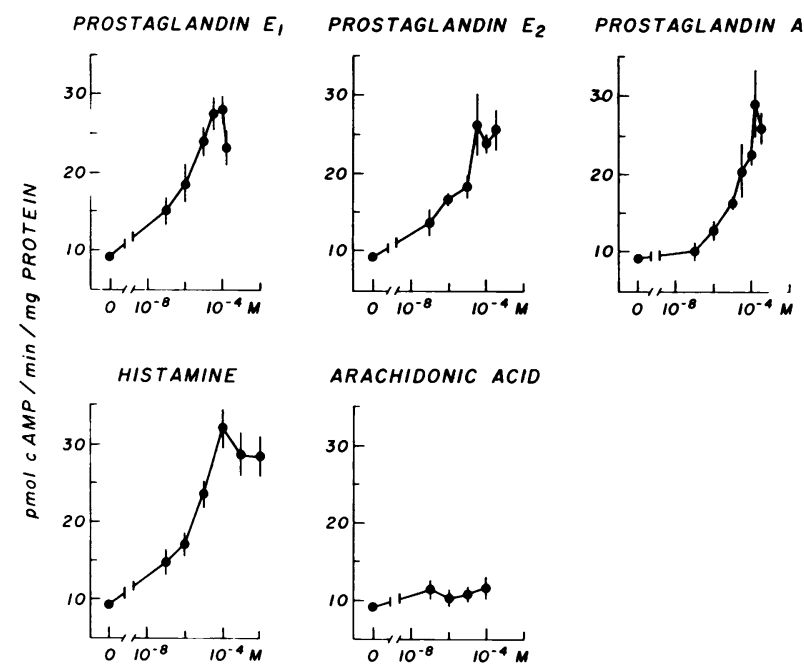

FIGURE 1 Effects of increasing doses of prostaglandins, histamine, and arachidonic acid on the fundic gastric mucosa adenylate cyclase activity. The points are means of three to seven observations \pm SEM. Ordinate, adenylate cyclase activity; abscissa, molar concentrations.

dependent between $10^{-7}$ to $10^{-4} \mathrm{M}$, and at the latter concentration, the maximum stimulation of adenyiate cyclase was achieved by all of the compounds (Fig. 1). Arachidonic acid did not stimulate the fundic mucosa adenylate cyclase significantly over this range of concentrations. A similar dose-dependent response of the adenylate cyclase to increasing concentrations of $\mathrm{PGE}_{1}, \mathrm{PGE}_{2}$, and $\mathrm{PGA}_{1}$ was found in preparations from antral gastric mucosa.

Using the maximal stimulatory concentrations, the combined effects of histamine and each of the three prostaglandins were determined. The results shown in Table II demonstrate that the addition of $10^{-4} \mathrm{M} \mathrm{PGE}_{1}$,
$\mathrm{PGE}_{2}$, or $\mathrm{PGA}_{1}$ to the fundic mucosa adenylate cyclase stimulated by $10^{-4} \mathrm{M}$ histamine did not interfere with the stimulation by histamine, but that the stimulation effects on adenylate cyclase were additive, i.e., the arithmetic sum of the stimulation by histamine and each of the prostaglandins tested individually did not differ significantly from the stimulation of adenylate cyclase when both agents in the maximal stimulating concentration $\left(10^{-4} \mathrm{M}\right)$ were added together into the same incubation mixture.

To further test whether histamine and prostaglandins act on two different receptor sites associated with fundic mucosa adenylate cyclase, the effect of metiamide, a specific $\mathrm{H}_{2}$-receptor antagonist, was tested on histamine and prostaglandin stimulation of fundic mucosa adenylate cyclase. Metiamide at concentration $10^{-4} \mathrm{M}$ produced only a slight inhibition of basal adenylate cyclase activity (Table III), and, as expected from our previous study (11), profoundly inhibited the stimulation of adenylate cyclase by histamine. However, the stimulation of adenylate cyclase by $\mathrm{PGE}_{1}, \mathrm{PGE}_{2}$, and $\mathrm{PGA}_{1}$ was not significantly influenced by metiamide, even when $\mathrm{H}_{2}$ receptor antagonist was added in molar concentration 10 times higher than prostaglandins (Table III). Likewise, metiamide had no inhibiting effect when adenylate cyclase was stimulated by $10^{-4} \mathrm{M} \mathrm{PGE}_{1}, \mathrm{PGE}_{2}$, or $\mathrm{PGA}_{1}$.

Prostaglandins $\mathrm{PGE}_{1}$ and $\mathrm{PGE}_{2}$, in the concentrations which markedly stimulated the adenylate cyclase activity, had no significant effect on the activity of the gastric mucosa cyclic AMP phosphodiesterase (Table IV). The $5 \%$ ethanol in which the prostaglandins were dissolved caused a reduction of cyclic AMP phosphodiesterase activity, but $\mathrm{PGE}_{1}$ and $\mathrm{PGE}_{2}$ did not further decrease the activity. PGA1 produced a small but significant inhibition of cyclic AMP phosphodiesterase prepared from

TABLE IV

Effect of Histamine and Prostaglandins on Cyclic AMP Phosphodiesterase Activity in Preparations from Fundic and Antral Gastric Mucosa

\begin{tabular}{|c|c|c|c|c|}
\hline & \multicolumn{4}{|c|}{ Cyclic AMP phosphodiesterase activity } \\
\hline & Fundic mucosa & $P$ value & Antral mucosa & $P$ value \\
\hline & \multicolumn{4}{|c|}{ pmol cyclic $A M P / \min / m g$ protein* } \\
\hline $\begin{array}{l}\text { Control } \\
\quad+\text { Theophylline } 10^{-2} \mathrm{M} \\
+ \text { Histamine } 5 \times 10^{-4} \mathrm{M}\end{array}$ & $\begin{array}{c}214 \pm 18 \\
40 \pm 3 \\
215 \pm 7\end{array}$ & $\begin{array}{l}-\overline{0.001 \ddagger} \\
\text { NSt }\end{array}$ & $\begin{array}{c}210 \pm 19 \\
40 \pm 3 \\
198 \pm 9\end{array}$ & $\begin{array}{l}-\overline{0.001 t} \\
\text { NSt }\end{array}$ \\
\hline $\begin{array}{l}\text { Control (5\% ethanol) } \\
\quad+\mathrm{PGE}_{1} 5 \times 10^{-4} \mathrm{M} \\
+\mathrm{PGE}_{2} 5 \times 10^{-4} \mathrm{M} \\
+\mathrm{PGA}_{1} 5 \times 10^{-4} \mathrm{M}\end{array}$ & $\begin{array}{l}180 \pm 10 \\
174 \pm 8 \\
172 \pm 7 \\
130 \pm 5\end{array}$ & $\begin{array}{c}<0.02 \ddagger \\
\text { NS\$ } \\
\text { NS\& } \\
<0.005 \S\end{array}$ & $\begin{array}{l}161 \pm 9 \\
151 \pm 11 \\
149 \pm 8 \\
111 \pm 5\end{array}$ & $\begin{array}{c}<0.05 \ddagger \\
\text { NS§ } \\
\text { NS§ } \\
<0.001 \S\end{array}$ \\
\hline
\end{tabular}

* Mean \pm SE from six observations.

$\ddagger$ For significance of difference from control without ethanol ( $t$ test).

$\S$ For significance of difference from control containing $5 \%$ ethanol ( $t$ test). 
both fundic and antral regions of gastric mucosa (Table IV). Cyclic AMP phosphodiesterase activity from the fundic and antral mucosa was strongly inhibited by theophylline, but histamine had no effect (Table IV).

\section{DISCUSSION}

Our results are in agreement with the preliminary communication of Perrier and Laster (4) reporting that $\mathrm{PGE}_{1}$ stimulates adenylate cyclase in gastric mucosa. We have found $P G E_{1}, P G E_{2}$, and $P A_{1}$ to stimulate an adenylate cyclase of fundic gastric mucosa in a dosedependent fashion. It is unlikely that this effect is due to a general physicochemical property of long-chained fatty acids since arachidonic acid, a fatty acid with physicochemical properties similar to prostaglandins had no effect on gastric mucosa adenylate cyclase. This action of prostaglandins is not limited to acid-secreting mucosa ; similar and even more prominent dose-dependent stimulation of adenylate cyclase occurred in preparations from antral gastric mucosa. In contrast to prostaglandins, histamine's stimulation of adenylate cyclase is limited to fundic mucosa (Fig. 1; references $6,7,11$ ). The mechanism by which prostaglandins inhibit gastric $\mathrm{HCl}$ secretion is not clear from previous observations (19). Our results indicate that they do not inhibit histamine-stimulated gastric $\mathrm{HCl}$ secretion by interfering with histamine-dependent cyclic AMP generation or by acceleration of cyclic AMP breakdown. On the contrary, we found that prostaglandins stimulate a gastric mucosal adenylate cyclase system which is different from that stimulated by histamine. This conclusion is based on two observations. First, the maximal stimulatory effects of prostaglandins and histamine on adenylate cyclase are additive and second, only histamine's stimulation is blocked by specific $\mathrm{H}_{2}$-receptor antagonist, metiamide. Our results suggest that these two adenylate cyclases are either in different compartments of the same cell or in two different cell types, one present in antral mucosa only but both present in fundic mucosa. This latter possibility is supported by results of a recent study showing that administration of histamine in vivo increased cyclic AMP tissue level in the layer of fundic mucosa, containing mostly oxyntic cells, while $\mathrm{PGE}_{2}$ increased cyclic AMP content in layers in which oxyntic cells were absent (27). Although both fundic and antral mucosa have some cell types in common (such as surface epithelium cells), it cannot be distinguished from the present results whether prostaglandin-sensitive adenylate cyclases from fundic or antral mucosa are derived from the same or from different cell types.

In conclusion, the present results clearly show that prostaglandins do not interfere with histamine-stimulated cyclic AMP formation; instead prostaglandins stimulate a different adenylate cyclase system in the gastric mucosa than histamine. It remains to be established whether prostaglandin-stimulated adenylate cyclase in gastric mucosa is a component of the cellular mechanism through which prostaglandins inhibit gastric $\mathrm{HCl}$ secretion or whether it is associated with some other, yet undefined, effect of prostaglandins in gastric mucosa.

\section{ACKNOWLEDGMENTS}

The expert technical assistance of Yvonne S. F. Hui and the secretarial assistance of Mrs. Joyce Wellik are gratefully acknowledged.

These investigations were supported by the U. S. Public Health Service, grant AM-16105 to Doctor Dousa, grant AM-17328 from the National Institute of Arthritis, Metabolism and Digestive Diseases to CURE (The Center for Ulcer Research and Education), by a research grant-in-aid from the American Heart Association, with funds contributed in part by the Minnesota Heart Association and by the Mayo Foundation.

\section{REFERENCES}

1. Way, L., and R. P. Durbin. 1969. Inhibition of gastric acid secretion in vitro by prostaglandin $\mathrm{E}_{1}$. Nature (Lond.). 221 : 874-875.

2. Nezamis, J. E., A. Robert, and D. F. Stowe. 1971. Inhibition by prostaglandin $E_{1}$ of gastric secretion in the dog. J. Physiol. (Lond.). 218: 369-383.

3. Wilson, D. E., G. Winnan, J. Quertermus, and P. Tao. 1975. Effects of an orally administered prostaglandin analogue $\left(16,16\right.$-dimethyl prostaglandin $\left.E_{2}\right)$ on human gastric secretion. Gastroenterology. 69: 607-611.

4. Perrier, C. V., and L. Laster. 1970. Adenylate cyclase activity of guinea pig gastric mucosa. Stimulation by histamine and prostaglandins. J. Clin. Invest. 49: 73a. (Abstr.)

5. Bersimbaev, R. I., S. V. Argutinskaya, and R. I. Salganik. 1971. The stimulating action of gastrin pentapeptide and histamine on adenyl cyclase activity in rat stomach. Experientia (Basel). 27 : 1389-1390.

6. Dousa, T. P., and C. F. Code. 1973. Stimulation of cyclic AMP formation in guinea pig gastric mucosa by histamine and $\mathrm{N} \alpha$ methyl histamine and their blockade by metiamide. In International Symposium on Histamine $\mathrm{H}_{2}$-Receptor Antagonists. C. J. Wood and M. A. Simkins, editors. Smith, Kline \& French Laboratories, Ltd., Welwyn Garden City, England. 319-330.

7. Sung, C. P., B. C. Jenkins, L. Racey Burnes, V. Hackney, J. G. Spenney, G. Sachs, and V. D. Wiebelhaus. 1973. Adenyl and guanyl cyclase in rabbit gastric mucosa. Am. J. Physiol. 225: 1359-1363.

8. Nakajima, S., B. I. Hirschowitz, and G. Sachs. 1971. Studies on adenyl cyclase in Necturus gastric mucosa. Arch. Biochem. Biophys. 143: 123-126.

9. Ray, T. K., and J. G. Forte. 1974. Adenyl cyclase of oxyntic cells: Its association with different cellular membranes. Biochim. Biophys. Acta. 320: 320-339.

10. Ohkura, H., and N. Hattori. 1975. Gastrin and histamine activated adenylate cyclase in isolated rat parietal cell. Adv. Cyclic Nucleolide Res. 5: 819. (Abstr.)

11. Dousa, T. P., and C. F. Code. 1974. Effect of histamine and its methyl derivatives on cyclic AMP metabolism in gastric mucosa and its blockade by an $\mathrm{H}_{2}$ receptor antagonist. J. Clin. Invest. 53 : 334-337.

12. McNeill, J. H., and S. C. Verma. 1974. Stimulation of rat gastric adenylate cyclase by histamine and hista- 
mine analogues and blockade by burimamide. $\mathrm{Br}$. J. Pharmacol. 52 : 104-106.

13. Bieck, P. R., J. A. Oates, G. A. Robison, and R. B. Adkins. 1973. Cyclic AMP in the regulation of gastric secretion in dogs and humans. Am. J. Physiol. 224: 158-164.

14. Karppanen, H. O., P. J. Neuvonen, P. R. Bieck, and E. Westermann. 1974. Effect of histamine, pentatastrin and theophylline on the production of cyclic AMP in isolated gastric tissue of the guinea pig. Naunyn-Schmiedeberg's Arch. Pharmacol. 284 : 15-23.

15. Wollin, A., L. D. Barnes, Y. S. Hui, and T. P. Dousa. 1975. Activation of protein kinase in the guinea pig fundic gastric mucosa by histamine. Life Sci. 17: 13031306.

16. Black, J. W., W. A. M. Duncan, C. J. Durant, C. R. Ganellin, and M. E. Parsons. 1972. Definition and antag-

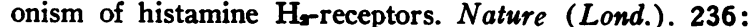
385-390.

17. Grossman, M. I., and S. J. Konturek. 1974. Inhibition of acid secretion in dog by metiamide: A histamine antagonist acting on $\mathrm{H}_{\mathrm{r}}$-receptors. Gastroenterology. 66 : 517-521.

18. Preiss, D. U., and C. F. Code. 1975. Effect of the $\mathrm{H}_{2-}$ receptor antagonists, burimamide and metiamide, on gastric secretion stimulated by histamine and its methyl derivatives. J. Pharmacol. Exp. Ther. 193: 614-620.

19. Kimberg, D. V. 1974. Cyclic nucleotides and their role in gastrointestinal secretion. Gastroenterology. 67 : 10231064.
20. Main, I. H. M., and B. J. R. Whittle. 1974. Prostaglandin $\mathrm{E}_{2}$ and the stimulation of rat gastric acid secretion by dibutyryl cyclic 3',5'-AMP. Eur. J. Pharmacol. 26: 204-211.

21. Whittle, B. J. R. 1972. Studies on the mode of action of cyclic $3^{\prime}, 5^{\prime}-\mathrm{AMP}$ and prostaglandin $\mathrm{E}_{2}$ on rat gastric acid secretion and mucosal blood flow. Br. J. Pharmacol. 46: $546 \mathrm{P}$.

22. Dousa, T., O. Hechter, I. L. Schwartz, and R. Walter. 1971. Neurohypophyseal hormone-responsive adenylate cyclase from mammalian kidney. Proc. Natl. Acad. Sci. U.S. A. 68: 1693-1697.

23. McKenzie, S. G., H. P. Bär. 1973. On the mechanism of adenyl cyclase inhibition by adenosine. Can. J. Physiol. Pharmacol. 51 : 190-196.

24. Sung, C. P., V. D. Wiebelhaus, B. C. Jenkins, P. Adlercreutz, B. I. Hirschowitz, and G. Sachs. 1972. Heterogeneity of $3^{\prime} 5^{\prime}$-phosphodiesterase of gastric mucosa. Am. J. Physiol. 223: 648-650.

25. Thompson, W. J., and M. M. Appleman. 1971. Multiple cyclic nucleotide phosphodiesterase activities from rat brain. Biochemistry. 10: 311-316.

26. Lowry, O. H., N. J. Rosebrough, A. L. Farr, and R. J. Randall. 1951. Protein measurement with the Folin phenol reagent. J. Biol. Chem. 193 : 265-275.

27. Katsumata, Y., and D. Glick. 1975. Effect of drugs influencing gastric secretion on the quantitative histological distribution of cyclic adenosine $3^{\prime}: 5^{\prime}$-monophosphate in the rat stomach. Gastroenterology. 69: 409-415. 